\title{
SOSIALISASI PENCEGAHAN PENULARAN COVID-19 MELALUI KULIAH KERJA PARTISIPATIF DARI RUMAH (KKP-DR)
}

\author{
Lalu Ahmad Didik' ${ }^{1}$, Farizal Wahyudi ${ }^{1}$ \\ ${ }^{1}$ Universitas Islam Negeri Mataram, Mataram, Indonesia \\ laludidik@uinmataram.ac.id
}

\begin{abstract}
Abstrak: Pandemi Covid-19 yang terjadi di seluruh dunia, khususnya di Pulau Lombok mengakibatkan program pengabdian kepada masyarakat yang dilaksanakan mahasiswa Universitas Islam Negeri (UIN) Mataram dalam bentuk Kuliah Kerja Partisipatif (KKP) dilaksanakan di lingkungan rumah mahasiswa masing-masing. Program ini selanjutnya disebut dengan Kuliah Kerja Partisipatif dari rumah (KKP-DR). Tema yang menjadi fokus dalam program ini adalah sosialisasi pencegahan penularan covid-19 dengan menekankan Perilaku Hidup Bersih dan Sehat (PHBS) yang sekaligus merupakan tuntunan agama Islam. Metode yang digunakan dalam program ini adalah sosialisasi kepada masyarakat di beberapa desa di Pulau Lombok yang merupakan desa asal mahasiswa. Program ini terdiri dari beberapa kegiatan seperti pemasangan pamflet dan penyebaran brosur, sosialisasi kampung sehat, seminar Perilaku Hidup Bersih dan Sehat (PHBS), pelatihan mencuci tangan, pembiasaan physical distancing, senam bersama, pemberian bantuan masker, pemberian bantuan hand sanitizer, dan bersih lingkungan masjid. Evaluasi dilakukan dengan mempertimbangkan manfaat program, ketepatan sasaran dan ketepatan metode yang diberikan kepada 10 orang kepala desa tempat mahasiswa melaksanakan KKP-DR. Hasil dari pelaksanaan program ini menunjukkan bahwa sebagian besar responden menyatakan sangat setuju dimana $100 \%$ responden menyatakan kegiatan ini bermanfaat, $80 \%$ tepat sasaran dan $90 \%$ menyatakan kegiatan ini menggunakan metode yang tepat. Kegiatan ini dapat membantu masyarakat mengetahui informasi seputar Covid-19 dan mampu memberikan bekal pencegahan penularan Covid-19 dengan menerapkan pola hidup bersih dan sehat.
\end{abstract}

Kata Kunci: kuliah kerja partisipatif dari rumah (KKP-DR), sosialisasi, pencegahan Covid-19

\begin{abstract}
The Covid-19 pandemic that hit the world, especially on the island of Lombok, makes students of the State Islamic University (UIN) Mataram carry out Participatory Community Service (KKP) program in their surroundings. This program is called home-based community program (KKP-DR). The focus of the program is the socialization on the transmission of COVID-19 prevention by emphasizing Clean and Healthy Lifestyle Behavior (PHBS), which is also an Islamic religious guidance. The method used was outreach to the community in several villages on the island of Lombok, where the students come from. The program was held in several activities such as the installation of pamphlets and distribution of brochures, socialization of healthy villages, seminars on Clean and Healthy Behavior (PHBS), hand washing training, physical distancing habituation, joint exercise, providing masks, providing hand sanitizer, and cleaning the mosques. The evaluation was carried out by 10 village heads considering the benefits of the program, the accuracy of the targets and the accuracy of the methods. The results of the implementation of this program are: $100 \%$ of respondents do agree that the program is useful; $80 \%$ of the respondents state that the program is effective; and 90\% agree that the program apply the right method. In conclusion, KKP-DR can help the public find out information about Covid-19 and be able to provide provisions for preventing the transmission of Covid-19 by implementing a clean and healthy lifestyle.
\end{abstract}

Keywords: KKP-DR, socialization, prevention of Covid-19 transmission

\section{Pendahuluan}

Pengabdian kepada masyarakat merupakan salah satu bentuk tri dharma perguruan tinggi yang merupakan tugas pokok dosen selain pengajaran dan penelitian. Kegiatan ini bertujuan 
untuk membantu kelompok masyarakat tertentu dengan tanpa mengharapkan imbalan (Churaez et al., 2020). Dalam konteks perguruan tinggi, pengabdian kepada masyarakat dtunjukkan dalam bentuk Kuliah Kerja Nyata (KKN) atau dalam konteks UIN Mataram dikenal sebagai Kuliah Kerja Partisipatif (KKP). Kegiatan KKP ini dilaksanakan mahasiswa dengan pendekatan lintas keilmuan dan lintas sektoral pada waktu dan daerah tertentu di wilayah Provinsi Nusa Tenggara Barat.

Pada KKP UIN Mataram tahun 2020, pola pengabdian yang dilakukan berbeda dengan pola pengabdian tahun sebelumnya. Hal ini disebabkan karena adanya pandemi Corona Virus Diseas 2019 (Covid-19). Covid-19 bukanlah virus pertama yang melanda Indonesia karena pernah ada virus selainnya seperti virus demam berdarah dan virus flu burung yang penyebarannya cukup massif. Namun, Covid-19 jauh lebih berbahaya karena daya sebar yang jauh lebih masif dan lebih mematikan dibandingkan virus lainnya (Wiratmo, 2020). Oleh karena itu, UIN Mataram menerapkan KKP dari rumah atau lebih dikenal dengan KKP-DR (Tim Penyusun Pedoman KKP, 2020). KKP-DR dimaksudkan supaya mahasiswa melaksanakan kegiatan KKP pada desa tempat tinggal masing-masing.

Meluasnya penyebaran Covid-19 di Indonesia berdampak pada semua bidang terutama karena sebagian besar masyarakat Indonesia, khususnya masyarakat pulau Lombok lebih banyak bergerak dalam bidang jasa yang tidak memungkinkan unuk menerapkan kerja dari rumah (Ausrianti et al., 2020). Hal ini tidak terlepas dari Pulau Lombok sebagai objek wisata yang sudah dikenal tidak hanya di Indonesia tetapi juga dunia (Kurniawati, Santosa, \& Bahri, 2020).

Dalam upaya mencegah penularan Covid-19 yang semakin meluas, maka pemerintah melakukan himbauan kepada seluruh lapisan masyarakat. Himbauan-himbauan tersebut antara lain melakukan jaga jarak (physical distancing), menggunakan masker, rutin mencuci tangan menggunakan sabun dan air mengalir, serta meningkatkan daya tahan tubuh dengan makan makanan yang bergizi (Sari, 2020). Namun dalam kenyataannya, kesadaran masyarakat Indonesia khususnya masyarakat Lombok yang masih tergolong rendah terkait kesehatan menyebabkan masih tingginya angka penularan Covid 19 di kalangan masyarakat.

Banyak kegiatan dilakukan untuk mengedukasi masyarakat agar sadar hidup bersih guna memutus penyebaran rantai Covid 19. Meri et al., (2020) melakukan Pemberdayaan Masyarakat dalam penggunaan hand sanitizer dan Masker sebagai upaya pencegahan penularan Covid-19. Churaez et al., (2020) melakukan pemberdayaan masyarakat dengan melaksanakan pembuatan dan penyemprotan disinfektan. Ausrianti et al., (2020) melakukan edukasi kepada masyarakat dengan memberikan bimbingan psikologi berupa dukungan kesehatan jiwa dan psikososial.

Sebelum menentukan kegiatan apa yang akan dilakukan oleh mahasiswa selama pelaksanaan KKP-DR nantinya, mahasiswa melaksanakan observasi awal. Adapun terdapat beberapa temuan yang didapatkan mahasiswa antara lain: (1) masih kurangnya kesadaran masyarakat akan pentingnya hidup sehat sehingga menyebabkan Covid-19 dapat dengan mudahnya menular di lingkungan masyarakat, (2) adanya golongan tertentu dari masyarakat yang cenderung meremehkan Covid-19 karena pengetahuan masyarakat tentang pencegahan Covid-19 yang masih rendah sehingga diperlukan edukasi terhadap kelompok tersebut dan (3) 
kurangnya ketersediaan masker dan hand sanitizer terutama di kalangan masyarakat desa sehingga diperlukan bantuan pengadaan masker dan hand sanitizer oleh mahasiswa.

Oleh karena itu, mahasiswa KKP-DR UIN Mataram Kelompok 17 melaksanakan upaya edukasi masyarakat di pulau Lombok dengan mengadakan edukasi kepada masyarakat tentang pentingnya hidup sehat dalam rangka pemutusan rantai penyebaran Covid-19 di Indonesia khususnya di Pulau Lombok.

\section{Metode}

Untuk mengatasi masalah yang didapatkan mahasiswa mengenai kurangnya kesadaran masyarakat akan dampak dan cara mencegah penularan covid 19 maka diperlukan suatu solusi. Adapun kerangka pemikiran pemecahan masalah dan konsep solusi yang ditawarkan ditunjukkan pada Gambar 1.

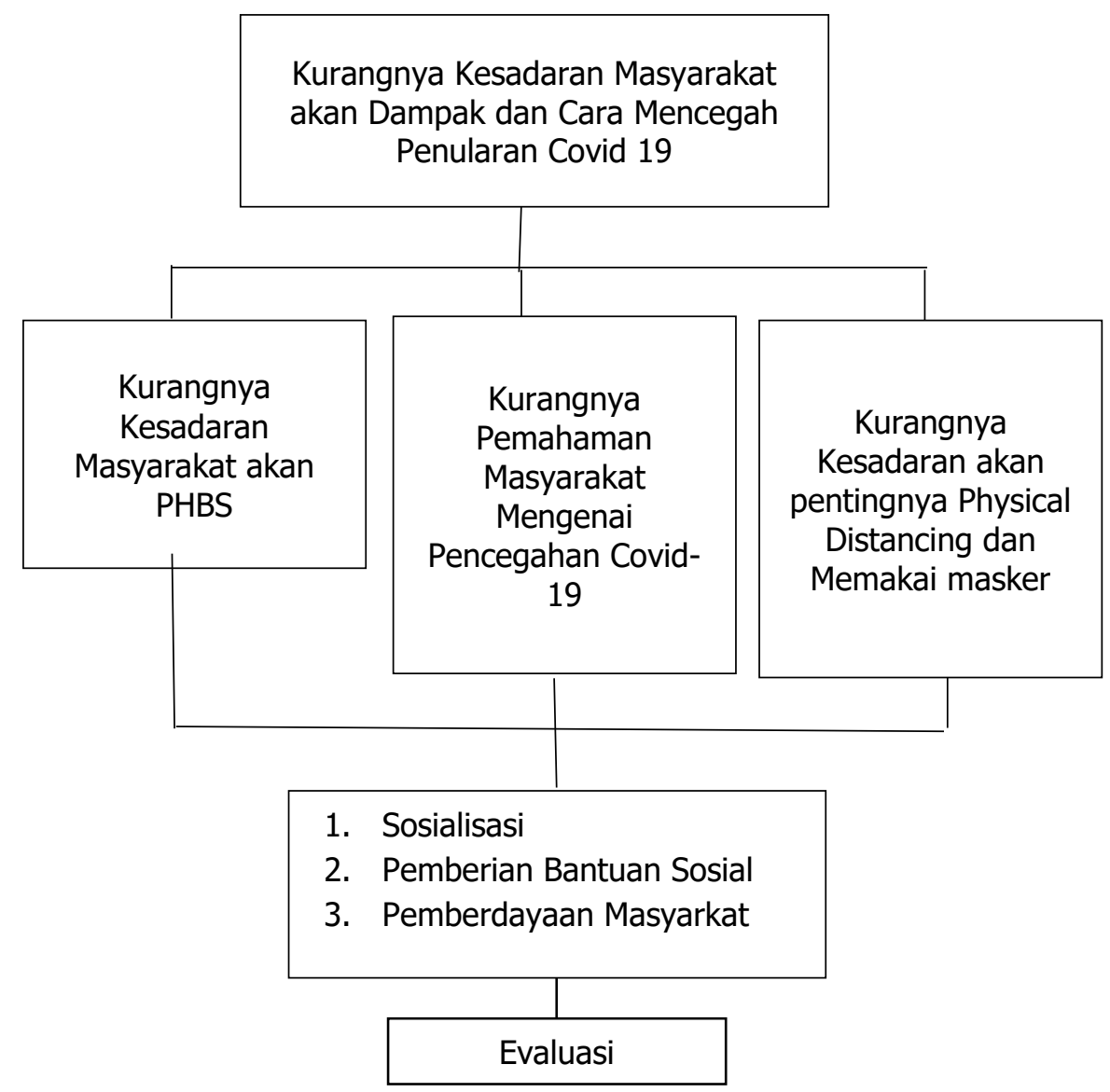

Gambar 1. Kerangka pemecahan masalah

Berdasarkan Gambar 1, tampak bahwa terdapat tiga permasalahan besar yang terjadi dalam masyarakat yaitu (1) Kurangnya Kesadaran Masyarakat akan PHBS, (2) Kurangnya Pemahaman Masyarakat Mengenai Pencegahan Covid-19 dan (3) Kurangnya Kesadaran akan pentingnya physical Distancing dan Memakai masker. Permasalahan seperti ini memang umum terjadi dalam masyarakat (Yanti et al., 2020). Oleh karena itu diperlukan suatu strategi dalam penanganan masalah ini yang dibagi menjadi 3 strategi yaitu: 
1. Sosialisasi mengenai Covid-19

Sosialisasi yang dimaksud disini adalah upaya pemberian pemahaman kepada masyarakat akan pentingnya budaya hidup bersih dan sehat untuk mencegah penularan Covid-19 di kalangan masyarakat. Adapun kegiatan yang dilakukan seperti Kegiatan Jum'at Bersih, Seminar Perilaku Hidup Bersih dan Sehat (PHBS), Senam bersama dan pemasangan pamphlet serta penyebaran brosur.

2. Pemberian bantuan sosial

Pemberian bantuan social dilakukan dengan cara pemberian bantuan berupa masker dan hand sanitizer kepada masyarakat.

3. Pemberdayaan masyarakat

Pemberdayaan masyarakat dimaksudkan supaya masyarakat dapat memenuhi kebutuhannya dalam pelaksanaan PHBS. Kegiatan yang dilakukan antara lain bersih lingkungan masjid, mengajar mengaji dan pelatihan pembuatan disinfektan dan hand sanitizer (Utomo et al., 2020).

Setelah pelaksanaan kegiatan dilakukan evaluasi menggunaan angket. Evaluasi ini meliputi kebermanfaatan program mahasiswa, ketepatan sasaran dan ketepatan metode pelaksanaan. Skala yang digunakan adalah skala likert sangat setuju, setuju, tidak setuju dan sangat tidak setuju (Didik, 2019). Angket diberikan kepada tiap kepala desa tempat mahasiswa melaksanakan KKP yaitu sebanyak 10 kepala desa.

\section{Hasil dan Pembahasan}

Selama melaksanakan kegiatan KKP, mahasiswa melaksanakan kegiatan-kegiatan yang telah disusun terlebih dahulu. Adapun bentuk kegiatan yang dilakukan oleh mahasiswa dalam rangka PkM melalui kegiatan KKP-DR ini ditunjukkan pada Tabel 1.

Tabel 1. Bentuk kegiatan pengabdian masyarakat melalui kegiatan KKP-DR

\begin{tabular}{lll}
\hline No. & \multicolumn{1}{c}{ Strategi } & \multicolumn{1}{c}{ Bentuk Kegiatan } \\
\hline 1 & Sosialisasi Covid-19 & 1. Pemasangan Pamflet dan Penyebaran Brosur \\
& & 2. Sosialisasi Kampung Sehat \\
& 3. Seminar Prilaku Hidup Bersih dan Sehat \\
& 4. Pelatihan Mencuci Tangan \\
& 5. Pembiasaan Physical Distancing saat Mengaji di \\
& & 6. Senam bersama \\
\hline 2 & Pemberian Bantuan Sosial & 1. Pemberian Bantuan Masker \\
& & 2. Pemberian Bantuan hand sanitizer \\
\hline 3 & Pemberdayaan Masyarakat & 1. Bersih lingkungan masjid, \\
& & 2. Mengajar mengaji \\
& 3. Pelatihan pembuatan disinfektan dan hand sanitizer \\
\hline
\end{tabular}

Berdasarkan tabel 1, tampak bahwa terdapat beberapa kegiatan yang dilakukan dalam upaya edukasi masyarakat mengenai bahaya Covid-19. Tidak lupa dalam setiap kegiatan diintegrasikan antara keagamaan dan social kemasyarakatan dan sains. Misalnya saja dalam 
seminar PHBS yang sangat berkaitan dengan ilmu taharah yang menjadi tahap dasar dalam melaksanakan ibadah. Tidak lupa masyarakat didorong untuk selalu menjaga kebersihan dengan bersama-sama membersihkan lingkungan sekitar dan tempat ibadah.

Dalam pelaksanaanya terdapat beberapa sub bagian kegiatan yang dilaksanakan dalam pelaksanaan sosilasi bahaya covid 19 kepada masyarakat. Kegiatan-kegiatan tersebut antara lain pemasangan pamflet dan penyebaran brosur, seminar prilaku hidup bersih dan sehat, pelatihan mencuci tangan, pembiasaan menjaga jarak sesama (physical distancing) saat mengaji di mushola dan senam bersama.

Berdasarkan bukti yang tersedia, Covid-19 ditularkan melalui kontak dekat dan droplet, bukan melalui transmisi udara (Mtthay, Aldrich, \& Gots, 2020). Resiko paling besar penularan adalah orang yang melakukan kontak erat dengan pasien Covid-19. Tindakan pencegahan merupakan faktor penting dalam pemutusan penularan Covid-19 (Telaumbanua, 2020). Langkah yang paling efektif antara lain:

1. Secara rutin membersihkan tangan dengan sabun pada air mengalir. Atau jika tidak memungkinkan, maka membersihkan tangan dengan menggunakan hand sanitizer.

2. Menghindari menyentuh mulut, mata atau hidung apabila berada di dalam keramaian.

3. Menutup mulut dan hidung menggunakan lengan atas atau tisu pada saat batuk atau bersin kemudian buanglah tisu tersebut ke tempat sampah

4. Selalu menggunakan masker medis apabila mengalami gejala pernapasan

5. Melakukan physical distancing dengan selalu menjaga jarak minimal $1 \mathrm{~m}$ saat berinteraksi dengan orang lain

Walaupun anjuran tersebut telah diumumkan oleh pemerintah, namun masih banyak warga masyarakat yang belum menerapkannya. Terutama bagi masyarakat yang berada di pedesaan karena keterbatasan masyarakat desa dalam memperoleh informasi. Disinilah peran mahasiswa untuk menghimbau warga masyarakat untuk selalu melakukan protokol kesehatan baik secara langsung maupun melalui media pamflet dan brosur. Gambar 2 menunjukkan pamflet yang digunakan mahasiswa dalam melaksanakan sosialisasi mengenai Covid-19. Subjek sosialsisai adalah para orang tua sehingga diharapkan mereka dapat lebih menjaga anggota keluarga masing-masing. Proses penyebaran pamflet dilakukan secara door to door. Pilihan ini dilakukan untuk menghindari perkumpulan warga serta menjamin warga mengerti dengan baik informasi yang diberikan.

Sosialisasi juga dilakukan dengan pemberian pemahaman warga dalam pelaksanaan hidup bersih dan sehat (PHBS). Salah satu kegiatan yang dilakukan adalah dengan rutin membersihkan lingkungan sekitar dan tempat beribadah selain secara rutin membersihkan tempat tinggal masing-masing seperti yang ditunjukkan pada Gambar 3. Selama pelaksanaan KKP, mahasiswa sangat aktif dalam mensosialisakan akan pentingnya PHBS baik di tempat tinggal sendiri maupun lingkungan tempat ibadah seperti yang ditunjukkan pada Gambar 3 (c) dan (d). selain itu mahasiswa juga aktif dalam membantu masyarakat dalam menerapkan program kampong sehat yang dicangkan pemerintah seperti yang ditunjukkan pada Gambar 3 (a) dan 3 (b). 

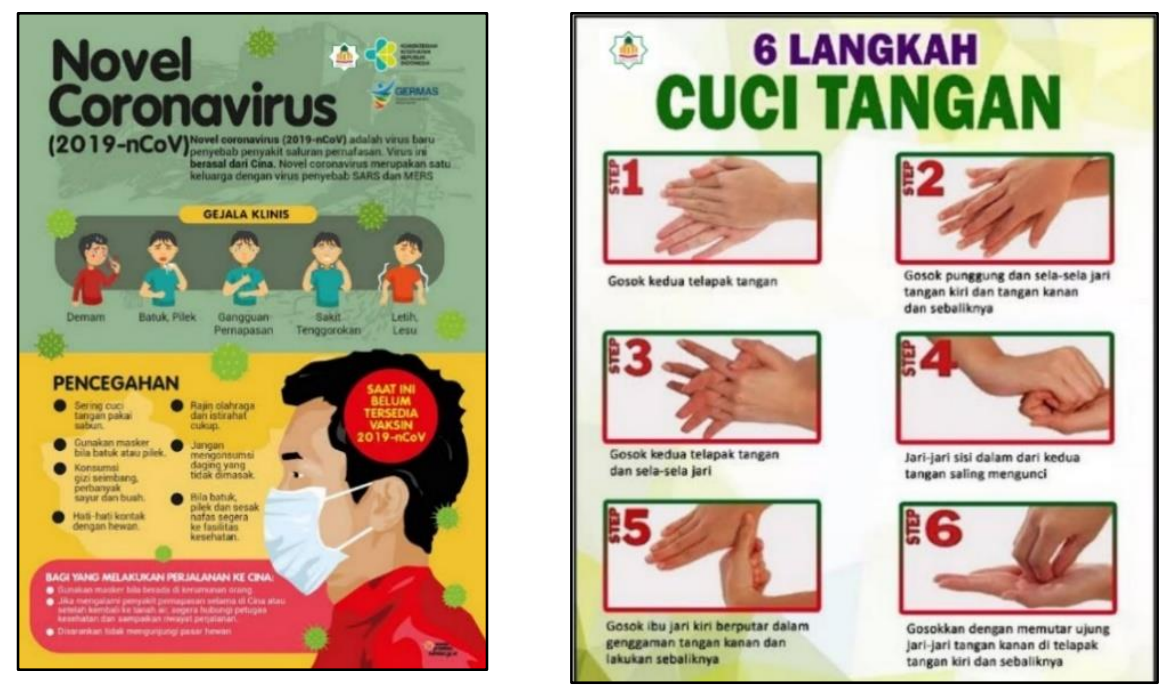

Gambar 2. Pamflet dan Brosur yang digunakan dalam Sosialisai Covid-19 kepada Masyarakat

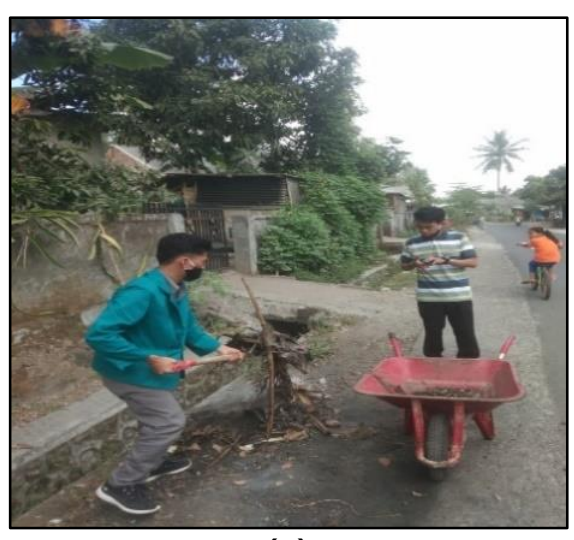

(a)

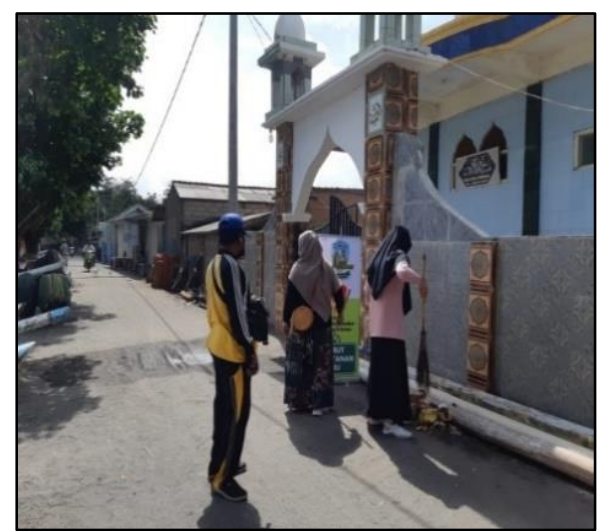

(c)

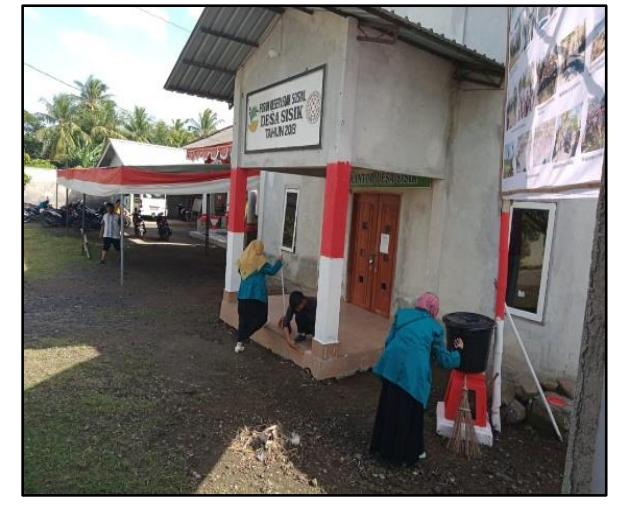

(b)

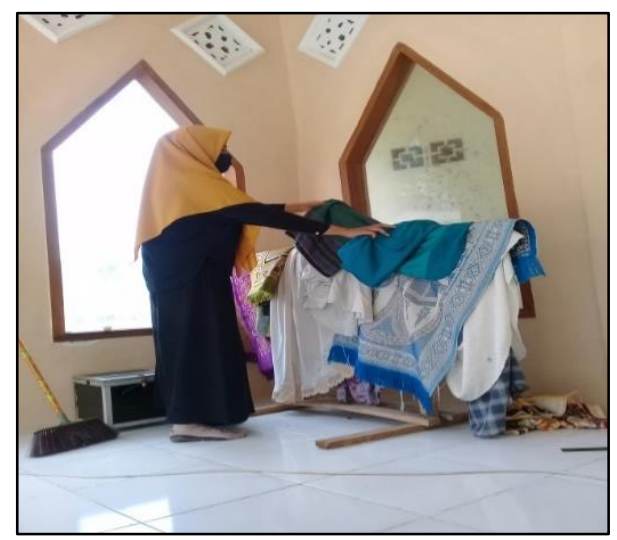

(d)

Gambar 3. Kegiatan Sosialisasi PHBS oleh Mahasiswa, (a) Pembersihan Lingkungan Tempat Tinggal, (b) Persiapan Kampung Sehat, (c) Pembersihan Lingkungan Sekitar Masjid, (d) Pembersihan Area di Dalam Masjid

Selain pembersihan lingkungan sekitar dan tempat ibadah, mahasiswa juga aktif memberikan pelatihan kepada masyarakat tentang perilaku hidup bersih dan sehat (PHBS). Salah satunya adalah bagaimana cara mencuci tangan dengan baik dan benar. Sosialisasi cara mencuci tangan yang benar merupakan salah satu faktor penting dalam upaya pencegahan penularan 
Covid-19. Hal ini disebakan tangan merupakan organ utama aktivitas manusia. Mencuci tangan dengan sabun dan air mengalir dapat membunuh kuman dan virus yang menempel di tangan kita (Meri et al., 2020). Dalam kenyataannya masih banyak warga masyarakat yang belum mengetahui bagaimana cara mencuci tangan yang benar. Hal ini disebabkan karena kebiasaan masyarakat yang masih kurang peduli dengan kebersihan diri sendiri.

Selain sosialisasi dengan menggunakan pamflet dan melakukan sosisalisasi PHBS, mahasiswa juga gencar menyerukan physical distancing dalam setiap kegiatan masyarakat baik kaitannya dengan interaksi di tempat social maupun interaksi di tempat ibadah. Physical distancing merupakan pembatasan jarak antar individu dalam pelaksanaan interaksi social. Berdasarkan hasil penelitian jarak minimum untuk menghindari penyebaran virus adalah 2 meter (Greenhalgh et al., 2020; Wiratmo, 2020). Dalam setiap kegiatan masyarakat harus menerapkannya baik dalam kaitannya dalam interaksi bersifat umum seperti pelaksanaan musyawarah desa maupun dalam kaitannya dalam konteks ibadah. Untuk mengingatkan akan adanya physical distancing, maka masyarakat senantiasa harus selalu diingatkan, misalnya dengan membuat tanda silang " $X$ " yang menunjukkan bahwa posisi tersebut tidak boleh ditempati oleh warga.

Dalam kaitannya dengan penerapan protocol kesehatan, selain dengan menerapkan physical distancing, masyarakat juga dihimbau untuk selalu menggunakan masker. Hal ini disebabkan karena penyebaran Covid-19 berasal dari droplet penderita Covid-19 yang menyebar saat batuk maupun bersin (Greenhalgh et al., 2020). Untuk menanggulangi hal tersebut, maka mahasiswa berinisiatif untuk mensosialisasikan penggunaan masker. Selain itu mahasiswa juga berinisiatif untuk membagikan masker secara sukarela kepada masyarakat seperti yang ditunjukkan pada Gambar 4(a).

Tidak semua masyarakat memahami arti pentinggnya penggunaan masker sebagai upaya preventif terhadap penyebaran Covid-19. Oleh karena itu tidak semua masyarakat menggunakan masker saat keluar rumah. Hal ini disebabkan karena kurangnya informasi tentang penerapan protokal kesehatan yang dicanangkan oleh pemerintah. Namun seiring dengan sosialisasi yang dilakukan oleh mahasiswa, masyarakat mampu memahami akan arti pentingnya penerapan protocol kesehatan sebagai upaya preventif terhadap Covid-19.

Selain dengan perilaku hidup sehat, maka kesehatan masyarakat harus dijaga melalui kegiatan olahraga seperti yang ditunjukkan pada Gambar 4(b). Dalam hal ini, mahasiswa melakukan kegiatan senam bersama dengan warga. Kegiatan ini juga didukung penuh oleh pihak desa. Kegiatan ini bertujuan selain sebagai sarana rekreasi fisik masyarakat juga diharapkan dengan melakukan olahraga secara rutin, imunitas individu dapat meningkat mengingat imunitas tubuh sangat diperlukan untuk mencegah penularan covid-19.

Setelah pelaksanaan program maka dilakukan evaluasi terhadap pelaksanaan program yang meliputi kebermanfaatan program, ketepatan sasaran dan ketepatan metode. Adapun hasil angket evaluasi ditunjukkan pada gambar 5 .

Gambar 5 menunjukkan hasil angket evaluasi program yang dilakukan oleh mahasiswa. Sebagian besar responden menyatakan sangat setuju mengenai kebermanfaatn kegiatan dimana $100 \%$ responden sangat setuju bahwa kegiatan ini sangat bermanfaat. Walaupun ada 
responden yang tidak setuju dengan ketepatan sasaran pelaksanaan KKP namun persentasenya sangat kecil yaitu hanya $10 \%$ saja.

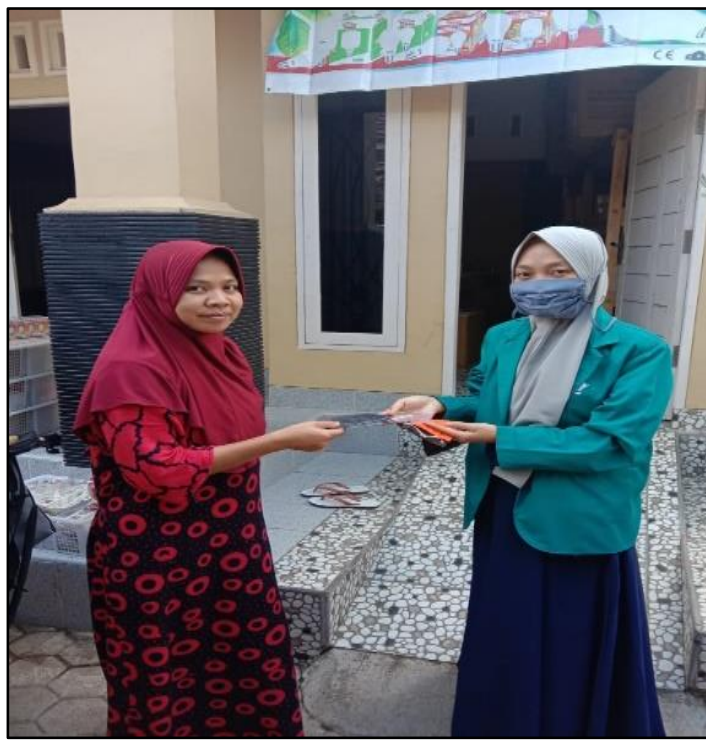

(a)

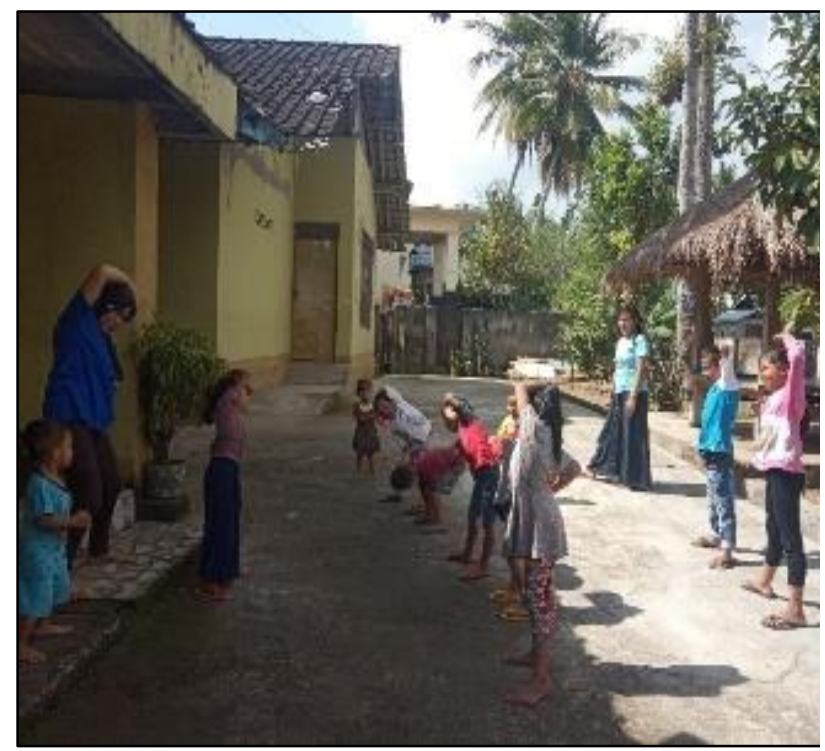

(b)

Gambar 4. Sosialisasi Hidup Sehat di Masa Pandemi (a) Sosialisasi Penggunaan Masker Sekaligus Pemberian Masker Gratis pada Masyarakat, (b) Senam Bersama dengan Social Distancing

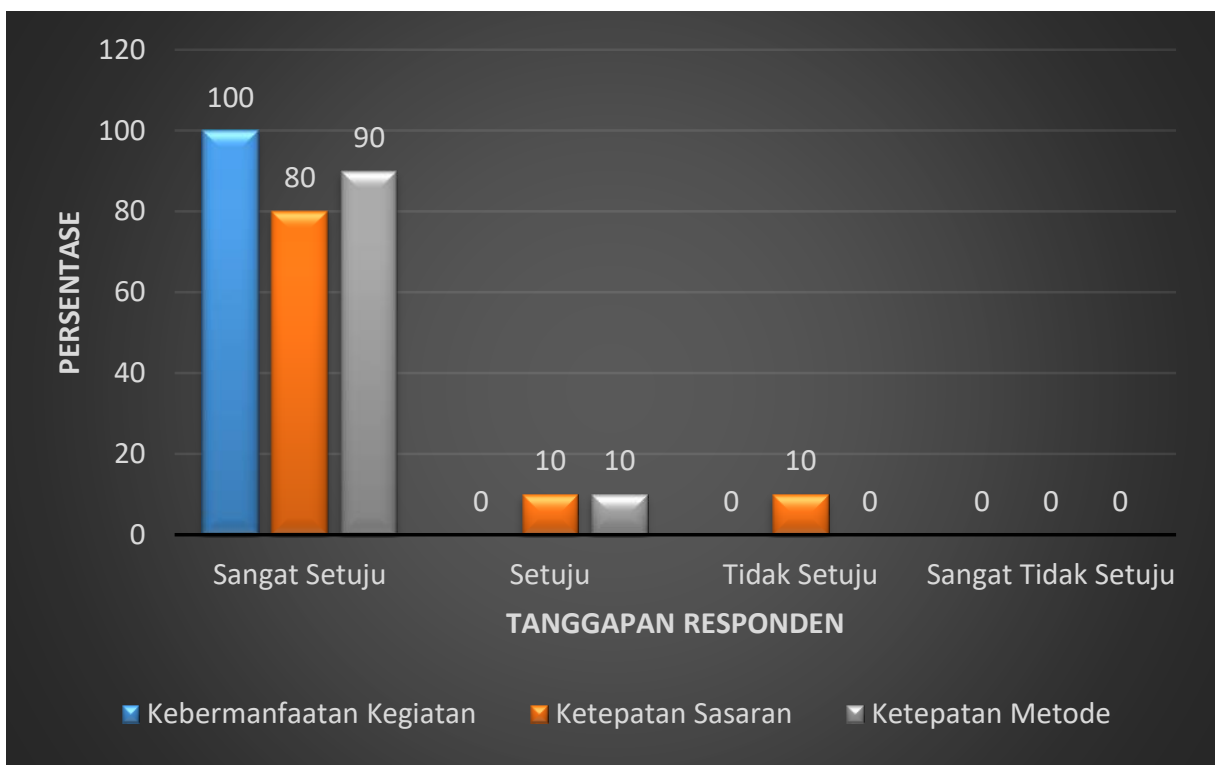

Gambar 5. Hasil evaluasi program

Kegiatan sosialisasi ini memiliki tujuan akhir supaya masyarakat dapat mengetahui tentang Covid-19 dan mampu melakukan pencegahan dengan menerapkan pola hidup bersih dan sehat (Yanti et al., 2020). Selain itu dengan memberikan pemahaman tentang protocol kesehatan, masyarakat mampu menerapkannya dalam kehidupan sehari-hari sehingga diharapkan penyebaran Covid-19 di lingkungan masyarakat Indonesia pada umumnya dan masyarakat Lombok pada khususnya dapat segera dihentikan. 


\section{Kesimpulan}

Dalam pelaksanaanya terdapat beberapa sub bagian kegiatan yang dilaksanakan dalam pelaksanaan sosilasi bahaya covid 19 kepada masyarakat. Kegiatan-kegiatan tersebut antara lain Pemasangan Pamflet dan Penyebaran Brosur, Seminar Perilaku Hidup Bersih dan Sehat, Pelatihan Mencuci Tangan, Pembiasaan Physical Distancing saat Mengaji di Musholla dan Senam bersama. Evaluasi dilakukan dengan memperhatikan kebermanfaatan program, ketepatan sasaran dan ketepatan metode. Hasil angket menunjukkan bahwa sebagian besar responden menyatakan sangat setuju dimana $100 \%$ responden sangat setuju bahwa kegiatan ini sangat bermanfaat. Walaupun ada responden yang tidak setuju dengan ketepatan sasaran pelaksanaan KKP namun persentasenya sangat kecil yaitu hanya $10 \%$ saja.

Kegiatan sosialisasi ini memiliki tujuan akhir supaya masyarakat dapat mengetahui tentang Covid-19 dan mampu melakukan pencegahan dengan menerapkan pola hidup bersih dan sehat. Selain itu dengan memberikan pemahaman tentang protokol kesehatan yang meliputi Perilaku Hidup Bersih dan Sehat, rutin mencuci tangan dan pembiasaan physical distancing, dalam kehidupan sehari-hari sehingga diharapkan penyebaran Covid-19 di lingkungan masyarakat Indonesia pada umumnya dan masyarakat Lombok pada khususnya dapat segera dihentikan.

\section{Ucapan Terima Kasih}

Terima kasih penulis ucapkan kepada Pusat Pengabdian Lembaga Penelitian dan Pengabdian Universitas Islam Negeri Mataram yang telah memberikan penulis kesempatan sebagai Dosen Pembimbing Lapangan dan Mahasiswa Peserta Kuliah Kerja Partisipatif Universitas Islam Negeri Mataram tahun 2020.

\section{Referensi}

Ausrianti, R., Andayani, R., Surya, D. O., \& Suryani, U. (2020). Edukasi Pencegahan Penularan Covid 19 serta Dukungan Kesehatan Jiwa dan Psikososial pada Pengemudi Ojek Online. Jurnal Peduli Masyarakat, 2(2), 59-64.

Churaez, F. I., Ramadani, R., Firmansyah, R., Mahmudah, S. N., \& Ramli, S. W. (2020). Pembuatan dan Penyemprotan Disinfektan: Kegiatan KKN Edisi Covid-19 di Desa Bringin, Malang. Sinergi: Jurnal Pengabdian, 2(2), 50-55. https://doi.org/10.31764/sjpu.v2i2.2485

Didik, L. A. (2019). Workshop Pembuatan Media Pembelajaran Listrik Magnet dari Barang Bekas untuk Meningkatkan Kompetensi Mahasiswa Calon Guru Fisika. Jurnal Pengabdian Masyarakat MIPA Dan Pendidikan MIPA, 3(2), 23-27. https://doi.org/10.21831/jpmmp.v3i2.25321

Greenhalgh, T., Schmid, M., Czypionka, T., Bassler, D., \& Gruer, L. (2020). Face Masks for the Public During Covid-19 Crisis Trisha Greenhalgh and Colleagues Argue That It is Time to Apply the Precautionary Principle. BMJ, 1435, 1-4. https://doi.org/htpps://doi.org/10.1136/bmj.m1435

Kurniawati, K., R., A., Santosa, F. H., \& Bahri, S. (2020). Sosialisasi Hidup Sehat di Tengah Wabah Virus Corona. JPMB: Jurnal Pemberdayaan Masyarakat Berkarakter, 3(1), 58-65.

Meri, Khusnul, Suhartati, R., Mardiana, U., \& Nurpalah, R. (2020). Pemberdayaan Masyarakat dalam Penggunaan Hand Sanitiser dan Masker Sebagai Upaya Preventif terhadap Covid-19. Bantenese Jurnal Pengabdian Masyarakat, 2(1), 26-33. https://doi.org/10.30656/ps2pm.v2i1.2340

Mtthay, M. A., Aldrich, J. M., \& Gots, J. E. (2020). Rational Use of Face Mask in the Covid-19. The Lancet, 8(May), 434-436. https://doi.org/10.1016/S2213-2600(20)30134-X

Sari, M. K. (2020). Sosialisasi tentang Pencegahan Covid-19 di Kalangan Siswa Sekolah Dasar di SD 
MInggiran 2 Kecamatan Papar Kabupaten Kediri. Jurnal Karya Abadi, 4(1), 80-83. https://doi.org/10.22437/jkam.v4i1.9821

Tim Penyusun Pedoman KKP. (2020). Pedoman Pelaksanaan KKP-DR UIN Mataram. Universitas Islam Negeri Mataram.

Telaumbanua, D. (2020). Urgensi Pembentukan Aturan terkait Pencegahan Covid-19 di Indonesia. Qalamuna - Jurnal Pendidikan, Sosial Dan Agama, 12(1), 59-70. https://doi.org/10.37680/qalamuna.v12i01.290

Utomo, A. P., Primaningtyas, W. E., Ahmad, M. M., Kusminah, I. L., Andiana, R., Nindyapuspa, A., Tjahyonowatie, S., \& Ningrum, D. S. (2020). Pelatihan Pembuatan Hand Sanitizer dan Aplikasi Pola Hidup Bersih di SMK Negeri 4 Surabaya dalam Menyikapi Pandemi Covid 19. Educivilia: Jurnal Pengabdian Pada Masyarakat, 1(2), 111-118.

Wiratmo, L. B. (2020). Sosialisasi Pemutusan Rantai Penyebaran Covid-19 di Kelurahan Tlogosari Kulon Kota Semarang. Jurnal Pengabdian Pada Masyarakat, 8(1), 57-65.

Yanti, B., Priyanto, H., \& Zulfikar, T. (2020). Sosialisasi Waspada Infeksi Corona Virus pada Lansia di Panti Jompo Rumoh Seujahtra Geunaseh Sayang, Dinas Sosial Aceh. Martabe: Jurnal Pengabdian Masyarakat, 3(1), 67-72. 